Comparative Philosophy Volume 5, No. 2 (2014): 45-68

Open Access / ISSN 2151-6014

www.comparativephilosophy.org

\title{
DIONYSIAN BIOPOLITICS: KARL KERÉNYI'S CONCEPT OF INDESTRUCTIBLE LIFE
}

\author{
KRISTÓF FENYVESI
}

\begin{abstract}
Scholar of religion Karl Kerényi's last book, Dionysos, is a grand attempt at reinterpreting $\zeta \omega \eta$ (zoe), the Greek concept of indestructible life, which he distinguishes from Bios (bios), finite life. In Kerényi's view, the meaning and sensual experience of zoe was expressed in its richest form in the Cretan beginnings of the cult of Dionysos. The major characteristics of this cult, as Kerényi describes, were beyond the cultural, political, and sexual limits of the Christian interpretations of life and nature. Searching for modern analogies to zoe, Kerényi explains the idea in relation to molecular biology's minimum definition of life. Despite the fact that Kerényi's book contains only minor references to contemporary philosophy, the philosophical consequences of his interpretations of Dionysos are not only radical but outline a notion of biopolitics far in advance of the mid-to late $20^{\text {th }}$ century development of it. By the affirmation of indestructible life and animality, Kerényi proposes a new humanism that moves beyond the limits of Kantian anthropology and also takes a radically different perspective to that of Heidegger's philosophy of being, or Agamben's notion of biopolitics. According to Kerényi's investigations, since this alternative humanism, which is based on the radical recognition of the individuality and diversity of life forms, was once possible in an earlier stage of human culture, it is possible to reanimate it in order to shape anew how zoe is understood and therefore lived. Our relation to nature can thereby undergo a Dionysian transvaluation and assign us new responsibilities as well as open up a new trajectory for the $21^{\text {st }}$-century human.
\end{abstract}

Keywords: Karl Kerényi, nature, religion, biopolitics, zoe, bios, Agamben

\section{INTRODUCTION}

The crowning achievement of Karl Kerényi's oeuvre, Dionysos: Archetypal Image of Indestructible Life, was published three years after his death, in both German (Kerényi 1976b) and later in English translation (Kerényi 1976a). While both editions were distributed by major publishing houses — Langen Müller Verlag and Princeton University Press -, the impact of Kerényi's Dionysos on philological and

FENYVESI, KRISTÓF: Postdoctoral Researcher, Department of Art and Cultural Studies, University of Jyväskylä, Finland. Email: fenyvesi.kristof@gmail.hu 
philosophical discourse has been rather circumscribed, even despite the centrality of its main critical concern (the idea of the indestructibility of life) to current philosophical debates. Although Kerényi's book aims to clarify the same concepts and questions recurring in discourses on biopolitics, and is in fact a foundational text on biopolitics, it is seldom referenced. Consider for instance that Kerényi's interpretation of Dionysos as the archetype of the indestructibility of life, and a cultic representation of the idea of zoe, is based on the distinction between the ancient Greek concepts of zoe and bios. In Homo Sacer, Giorgio Agamben's interpretations and distinctions are quite similar, if not largely analogous, but in relation to these concepts, he never engages with or even cites Kerényi's text, which complicate and problematize how Agamben uses the concepts and thus necessitate confronting them. While Agamben's main concepts are still in many ways at the center of debates on biopolitics, his indebtedness to Kerényi is not apparent. It is noteworthy that Agamben's only explicit references to him are when he discusses homo sacer's mythological background (Agamben 1998: 73-74; 182-183), but not when he introduces 'his' idea of bare life (la vita nuda), which is based on Kerényi's explication of the Greek notion of zoe. Kerényi's La religione antica nelle sue linee fondamentali (1940a), which Agamben frequently refers to (Agamben 1998: 193), deals with the ancient Greek concept of bios as well (Kerényi 1962: 27-28; 158; 162; 265), yet more than three decades before Agamben would address the concept. Further, the epilogue to the book would play a key a role in the development of Agamben's bios-zoe concept. ${ }^{1}$ Moreover, Kerényi found the introduction of the relationship between bios and zoe so fundamental to his thought that he called attention to the bios-zoe relationship as the leading focus of his book (Kerényi 1962b: 11-15). Kerényi even defines his main method as biotic (as opposed to vitalistic or existentialist), setting himself in opposition to both Bergson and Sartre:

The way here indicated of looking at things is no less historical than any which has claimed to be so in the past study of ancient religion. It is neither 'vitalistic' not 'existentialist' but 'biotic' - in the previously given meaning of the word 'bios' [...]. [...] The idea that it had from the beginning, of preparing a 'Philosophy of Ancient Religion', has not for that reason been abandoned. But if the method chosen is 'biotic', it must take with it a good deal of those forms of experiences mediated, as I have said, only by works of art. (Kerényi 1962b: 15-16.)

Although Kerényi did not yet thematize the question of zoe and bios (Kerényi 1940b; 1940a), he did not name his method biotic until two decades later. However, he does mention the concept of bios in both editions as well as in his introduction to the 1962 revised edition, providing clear evidence that, already beginning with the book Agamben refers to (Kerényi 1940b), Kerényi attached considerable importance to the topic, and the problem of the ancient relationship of life to death became a separate

\footnotetext{
${ }^{1}$ See in the English edition Kerényi's The Religious Idea of Non-Existence (Kerényi 1962: 261-279).
} 
thread in his extensive research of antiquity. The question of the ancient Greek interpretation of bios and zoe can also be found in Kerényi's Der frühe Dionysos (1961), just as in his Die Mysterien von Eleusis (1962a). Subsequently, in 1963, he explored this question in an essay, "Schicksal, Leben und Tod nach griechischer Auffassung" (1963b), and further refined the differential approach to the ancient Greek relationship to life, based on the distinction between zoe and bios. The bios-zoe thematics then culminated in Kerényi's ambitious presentation of the cult activities connected to zoe in his Dionysos (1976a, b). Since he devoted comprehensive work to both aspects of the ancient concept of life, we can accept Kerényi's claim that, in The Religion of the Greeks and Romans, he was preoccupied with the bios-concept of antiquity (Kerényi 1962a: 11-13) and with zoe in his Dionysos. His research is formative and his insights are relevant to contemporary western biopolitical thought. This is especially true in relation to Agamben, who builds his whole biopolitical approach on the duality of bios and zoe just as he bases his reinterpretation of zoe on his bare-life concept. To understand the genealogy of these concepts, it is necessary that Agamben, and those engaging in contemporary biopolitical discourse who contest his bare life/zoe-interpretation, confront those elements of Kerényi's work that have a direct relationship to Agamben's inquiry. Otherwise, no comprehensive inquiry of biopolitics is possible. ${ }^{2}$

After identifying all of these discursive omissions, I will provide a short introduction to Kerényi's Dionysos from a biopolitical perspective and devote special attention to his interpretations of bios and zoe as well as to the ancient Greek notion of the indestructibility of life. I will then examine Agamben's notions of bios and zoe, particularly his notion of "bare life", and trace out how it is both parallel to and different from Kerényi's interpretation of zoe, for Agamben introduces his notion of bare life as a modern reinterpretation and specific, new appearance of zoe. Finally, I will call attention to certain aspects of Kerényi's humanism which suggest that Kerényi was aware that his own research pointed toward areas now seen as fundamental aspects of biopolitical inquiry.

\section{DIONYSOS AND THE IDEA OF INDESTRUCTIBLE LIFE}

While the basic concepts of Kerényi's Dionysos (1976a) originate in insights he had as early as the 1930s (see: Kerényi 1935a, b), Dionysos also incorporated much of Kerényi's research from the 50s-60s (e.g., Kerényi 1956; 1957; 1961; 1962a, b;

\footnotetext{
${ }^{2}$ Osamu Kanamori, the author of Philosophy of Genetic Modification (2005), is one of the few if not the only biopolitical thinker to date who recognizes the potential of Kerenyi's bios-zoe interpretation. Kerényi's work is an important and productive reference point for Kanamori (cf. 2007), who sometimes mentions its relationship to Agamben's biopolitical concept (cf. 2008). But the critical comparison of Kerényi's and Agamben's bios-zoe concepts and the examination of the contemporary biopolitical potential of Kerényi's concept of the indestructibility of life and the possible biopolitical aspects of Kerényi's humanism are not the subjects of Kanamori's research. See the artist's introduction to his own works for an elaboration of his indebtedness to Kerényi: $<\underline{\text { http://www.art- }}$ is.com/en/aikowadagallery/exhibition/2013/ai makita 1317/> Retrieved: 28. 2. 2014.
} 
1963a, 1963b; 1967). He developed his specific research method, the so-called sensuous tradition of antiquity, in the 30 s as an original methodological contribution to Classical Studies under the influence of Geistesgeschichte, and he would further develop this method throughout his whole career. ${ }^{3}$ Similarly to the other works Kerényi based on the archetype theory, ${ }^{4}$ in Dionysos, he relied in part on Jungian psychoanalysis, ${ }^{5}$ and the experimental concepts of the predecessors of the cultural turn in modern ethnology and social anthropology. By the implementation of this rich transdisciplinary methodology, Kerényi made an explicit distinction between the myths of the Greeks and modern myths created in association with Greek myths. He both called attention to the radical division and cultural difference between antiquity and the present world and also stressed that the reflexive study of antiquity and the careful and prudent manifestations of these cultural differences might also lead to productive tendencies in contemporary culture (Kerényi 1976a: xxiii-xxix).

Kerényi's basic research method included literally everything that directly or indirectly merged or had contact with the ancient world. Since this method is largely unknown, instead of summarizing and paraphrasing it, despite the length of this passage from his 'Unsinnliche und sinnliche Tradition' (Kerényi 1980), it will be informative to let Kerényi's own words resound. In this essay, he describes the antique book as an object, which with its material, sensuous aspects, also belongs to the sensuous tradition of antiquity:

Es ist der Buchkörper, durch den das Buch in die »sinnliche Tradition« des Altertums gehört; in seinen späteren Formen gehört es in die Tradition späterer Zeitalter. Das Leben hat sich in jedem Zeitalter und jeder Kultur seit dem Altertum eine eigene Buchform geschaffen, genau wie es sich eine Tempelform, ein eigenes Wohnhaus oder eigene Trachten schuf: Hüllen, die zu ihm gehören, wie zur Schnecke das Schneckenhaus. Das ist das Wesen der »sinnlichen Tradition«: Leben hat sie geschaffen, das in ihr wohnte und sich ihr wieder entzogen hat. Jedes Stück dieser Tradition ist ein Lebensrest, der einen Lebensaspekt und einen Todesaspekt hat: einen Lebensaspekt, insofern er von dem Leben zeugt, das sich aus ihm zurückgezogen, einen Todesaspekt, insofern er als eine starre, leergewordene Hülle vor uns liegt. Er hob das Leben in die Erstarrung empor, und auf diese Weise erhielt er es - auf der Ebene eines langsamer sterbenden Lebens: des Lebens der Dinge. Das Buch als Antiquität ist ein hinterlassenes Stück antiken Lebens, ein aus seinem Zusammenhang gerissenes, hin und her getragenes, totes Ding, doch warm noch von der Wärme jener Menschen, die es verfertigt und gebraucht haben. Es »schmeckt« nach demselben Leben, ist nach der Seele des gleichen Lebens gebildet, das die ganze antike Kultur geschaffen hat; nicht anders als das Leben der Fichte die Fichte und den Fichtenzapfen bildet. (Kerényi 1980: 68)

\footnotetext{
${ }^{3}$ For the first detailed description of the sensuous tradition of antiquity as a research method in Hungarian, see: Kerényi 1934; for the description's shorter, German version, see: Kerényi 1937. For its more detailed version in German, see: Kerényi 1980. Simon (2011) provides a comprehensive summary of the method and its genealogy in Kerényi's oeuvre.

${ }^{4}$ See the The Bollingen Series nr. 65 of Archetypal Images in Greek Religion in five volumes: Kerényi 1959; 1963a; 1967; 1975; 1976a).

${ }^{5}$ See his work written jointly together with C.G. Jung (Kerényi 1969).
} 
Amongst other approaches, Kerényi's sensuous approach also explains why, contrary to other classical-philologists of his age, whenever possible, he frequently used illustrations, which provided a detailed, more comprehensive overview not only of ancient textual material, but of the visual culture and atmosphere as well, thereby not constricting his research solely to textual matter. For modern researchers and enthusiasts, complex research, analytic papers, and scientific structures are needed to 'understand' Dionysianism whereas for the members of the cult, it was enough to have images, without any further analysis, from which a whole pattern of associations started to function. Kerényi explains this visual if not elemental aspect:

The surviving material from which our knowledge of ancient religion is derived is both literary and visual. [...] The idea of religious style, which is the basis of the approach to ancient religion here adopted, makes particular demands on the illustrator. The elucidation of words and concepts leads us again and again to the world of vision, particularly in the case of Greece, where knowing was seeing, religion was spectacle, and the divine view was the divine act. (Kerényi 1962b: 2)

Kerényi recognized that Dionysos' central role in Greek culture was indicated by the fact that Dionysos was represented in a multitude of architectural remains and artifacts, suggesting that his impact is far greater than that of any other Greek god. The sheer abundance of remaining ancient theaters - as Dionysian cult-places and viniculture corroborates this view. As Kerényi notes:

No other god of the Greeks is as widely present in the monuments and nature of Greece and Italy, in the 'sensuous' tradition of antiquity, as Dionysos. We may almost say that the Dionysian element is omnipresent. The two characteristic products of Greek architecture of which we possess the greatest number of ruins or vestiges are the temple and the theater. One of these, the theater, belonged to the domain of Dionysos. And of all the cultivated plants of antiquity, it is the vine that has survived most abundantly: it too was sacred to Dionysos and bore witness to his presence. (Kerényi 1976a, xxiv-xxv)

Kerényi explained the relationship between theater and viniculture from a peculiar aspect: after empirical examination of the remains of the ancient theater at Cumae, with its abundance of vegetation, bushes, trees, and mainly vines, he discerned in 1931, thirty-eight years before the finalization of the Dionysos manuscript (Kerényi 1976a, xxv), that theater and viniculture are connected; therefore, Dionysos' character was not only ecstatic but vegetative. The strong presence of this vegetative element made an impact on Kerényi, and just as did the image of the theater, it became a guiding symbol in his Dionysos studies (Kerényi 1976a, xxv). Kerényi managed to place the equally important characteristic of the vegetative aspect next to the cultic reality of Dionysian intoxication, ecstasy, and animalism, as emphasized by Otto. This led to a further refining of the natural embeddedness of the godhead: 
Das Überschäumen in pflanzlicher Form als Symbol und Epiphanie des Dionysos [...] Pflanzen, mit ihrem Säften und Kräften die "Gleichnisse des Gottes selbst" — wie Otto im besonderen von Weinrebe und Efeu zeigt — oder Pflanzliches mit bestimmten Eigenschaften, wie der Pinienzapfen in seiner Starrheit mit dem Samen des Lebens, sind bereits 'Realität.' Diese naturhafte Realität, welche ebenso, wie die seelische, die Erscheinungsform der höheren Realität 'Dionysos' ist [...] zwar als etwas Formgebendes für seinen Kult. (Kerényi 1935a: 33.)

Kerényi explained that "any account of the Dionysian religion must put the main accent not on intoxication but on the quiet, powerful, vegetative element which ultimately engulfed even the ancient theaters, as at Cumae" (Kerényi 1976a, xxv). The Cumae theater, overgrown with vines, is an still active representation of Kerényi's idea, if not a medium of it (Fig. 1).

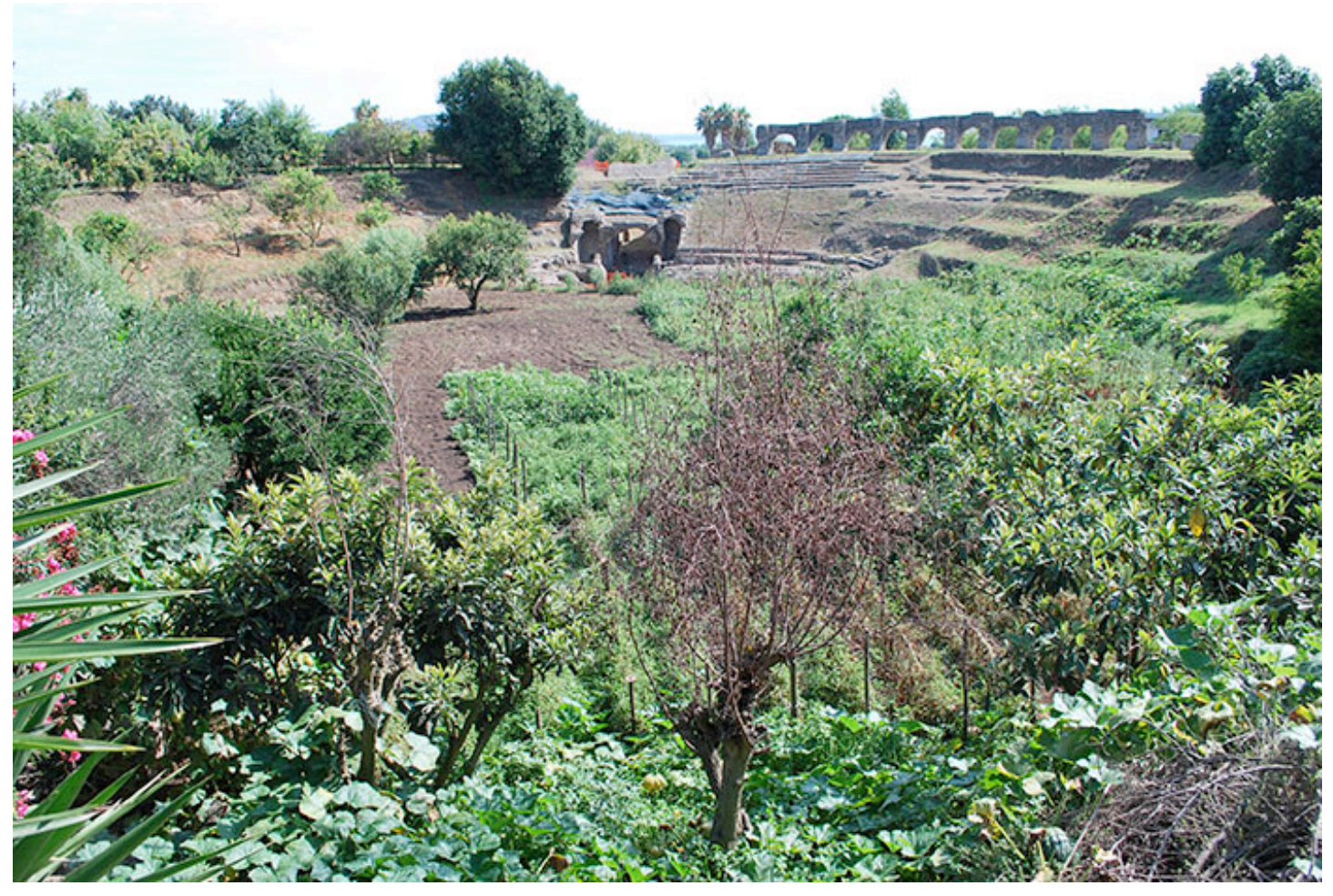

Figure 1: The ancient theater at Cumae, Naples, Italy. Photograph by Rien Bongers. Source: <http://antiekpubliek.blogspot.com/2011/07/great-grapevine-amphitheater-ofcumae.html> - retrieved on 28.2.2014.

In order to further detail the impulses behind his Dionysos concept, Kerényi relied on Otto's 1933 Dionysos: Mythos und Kultus, as he himself explains here:

With his Dionysos: Mythos und Kultus, Walter Friedrich Otto anticipated my plan, which in any case was still far from maturity. In his monograph, Otto treated the material from a 
high spiritual point of view, primarily on the basis of the literary tradition, and attempted to appraise the experience expressed in that material. He did not portray the god as the bestower of a passing intoxication. [...] Nor did Otto ever gain awareness of the limited character of his own reaction to the ancient phenomenon: to the erotic feature of the Dionysian element he remained closed. (Kerényi 1976a, xxv-xxvi.)

Otto viewed cults, such as the Dionysian, as creative activities, even as languages (Otto 1965, 18-19). In his analysis, the cult as a language is a tool that helps in regulating the proximity between the transcendent world and the human (Otto 1965, 20). This cult-language, in Otto's interpretation — to some extent parallel to Kerényi's concept on the sensuous tradition of antiquity — includes all communicative phenomena, such as artworks and non-verbal, corporeal actions as well. In Otto's interpretation, the people participating in the cultic activities are represented as bodies practicing the language of the cult. They form the image of the omnipotent godhead with their own bodies, thus its reality is reflected in the participants' solemn actions long before the godhead's inexpressible or untold myth could have presented itself in eloquent narratives or in poetry (Otto 1965, 22). Starting from this idea, Otto went beyond traditional methods of interpreting the linguistic materialization of religious concepts and beliefs and concentrated directly on the reality of the godhead (Otto 1965, 24). He examined the interdependent relation between the images and representations of the godhead as created by the cult and the cult's self-representations, made for its members, who create and participate in the rituals. The cult members' whole life is expressed in their 'cult,' practically everything that we call culture. Culture is guided by myths (Otto 1965, 30-31.) working in the depths of the cult, and manifested in the experiences, thoughts, sensuality, and will, all of which provide the culture's content. In Otto's interpretation, which probably had the most decisive impact on Kerényi, the experience of the godhead is not some type of metaphysical experience, but a real world-experience: it is a powerful experience wherein knowledge of the world corresponds with the configuration of the godhead's myth. Otto opposes Hegel, who had drawn attention to the ethical and moral interpretations of human finitude and mortality, and relies more on Nietzsche, who sees sensuality and cruelty as simultaneously present in Dionysos. Nietzsche also recognized the uncontrollable elementary force in the transitory features of the Dionysian character, which uphold the continuity of creation and destruction infinitely and which are continuously directed at becoming (Otto 1965, 135). In Otto's view, the paradox of the Dionysian phenomenon - the joint presence and peculiar unity of endless, indestructible life and cruel destruction; enthusiastic joy and panic terror; absolute closeness and endless distance - is nothing less than the cultic expression of the cosmic enigma, of the mystery of life that "arises from itself and creates from itself" (Otto 1965, 136), of the outrageous and transforming experience that springs from the deep intuition that fascinated the Greeks.

Otto also lent insight to the articulation of all of these experiences within the scope of human life and presented the liminal rites that accompany the changes of the individual's social role as he ages. In the Dionysian rites, the dreadful manifestation 
of death, which ever so often lurks in the depths of life, draws attention to the irreversible alteration of the rhythm of life with the passing of time (Otto 1965, 138). In the domain of ancient Greek culture, images expressing the experience of the continuous macro- and micro-cosmic transformation, play a central role. Like the transformative force of fire, the transformative and intoxicating power of wine is also created through the transformation of the grape. For Kerényi then, the images of the trailing grapevine as the plant of transformation also play a central role in pictorial representations. But this does not at all mean that the activity of Dionysos would be restricted to the world of plants. Be it in the form of plant, animal, or human, the rawest and sometimes most atavistic manifestations of the creative power of the biological can often refer to the closeness of Dionysos: "In the case of Dionysos, a biological interpretation seems most relevant and remains indispensable as a working hypothesis" (Kerényi 1976a: 204f). Dionysos' universal natural and biological /zoological characteristics are also symbolized in the unified use of the mask (Kerényi 1976a: 80-81) and the ivy-wreath in the Dionysian celebrations (cf. Kerényi 1935a: 33-40).

To prepare the ground for his multifold Dionysos-interpretation, Kerényi used a Goethe quotation as the motto to his Dionysos: "Perhaps in this way we shall attain the high philosophical goal of perceiving how the divine life in man is joined in all innocence with animal life" (Kerényi 1976a, vi). Following Goethe's aim, Kerényi commences his book by interpreting the difference between the ancient Greek notions of finite life, Bios (bios), and infinite life, $\zeta \omega \eta$ (zoe). According to Humboldtian linguistic philosophy, an inherent set of experiences, or shared knowledge, has been accumulated and made available to the speakers of a language. These experiences act as a pre-philosophical frame to their thinking, which is bound to language from the beginning (Kerényi 1976a, xxxi). In Latin, the word for life is vita, which has a wide range of meanings and the associative context of experiences as well as its equivalents in other languages. Kerényi stresses the fact that the Greeks used two different words, Bios (bios) and $\zeta \omega \eta$ (zoe), to express the meaning that is concealed in the single Latin expression. According to Kerényi's interpretation, the two Greek words are the linguistic manifestations of two different experiences. The Greeks referred to life in general as zoe, without any further characterization. Zoe describes the function of living organisms, now considered to be part of the biological sciences. Kerényi presents examples from Homer, when the verb zoein is used to describe an uncharacterized and not particularly emphasized state of enduring life that signifies the 'minimum of life'. For the gods, it is easy to sustain this state of endurance; accordingly, their life in general is also described with the notion of zoe (Kerényi 1976a, xxxiii). In contrast, bios refers to specified life, the characterized life of a unique creature. Bios itself is the content of an individual life; everything that can be summarized in a biography. According to Kerényi: "Bios is attributed also to animals when their mode of existence is to be distinguished from that of plants. To plants the Greeks attributed only physis - except when a mode of living was to be characterized" (Kerényi 1976a, xxxii). On the other hand, zoe is infinite life; as a result, it cannot be summarized; it is not describable. Since the basis of every 
individuation is represented by zoe, the core of experience concerning zoe cannot embrace the experience of evanescence or ceasing. Death always happens on the level of bios, individual life, and not on the level of zoe, which serves as a basis for all individual bios. The experience of zoe is the most direct, the most private, and the most inevitable experience of all living, which precedes in every aspect the experience of bios, which is the awareness of individualization. Since bios contains both individual life and individual death, thanatos as eternal death in its spiritual meaning is not the opposite of bios but rather of zoe, which is the form of infinite life: "Zoe seldom if ever has contours, but it does contrast sharply with thanatos. What resounds surely and clearly in zoe is 'non-death'." That is why the notion of soul, that is psyche, is not associated with bios, but zoe. This is reflected later in such philosophically elaborated significant thoughts as the concept of the immortality of the soul, for example in Plato's Phaidon, and the religious carrier of this mythologem (Kerényi 1976a: xxxiv, 124-125). The sharp distinction between zoe and bios refers to that which in Greek culture is the experience of indestructible life and which serves as the basis for every type of individual life.

To Kerényi, the notion of life in modern biology cannot be related to bios. The word biologos meant to the Greeks a mime who imitated the characteristic life of an individual and by his imitation made it appear still more characteristic (Kerényi 1976a: xxxiii). From the Greek point of view, modern biology should be called zoology: "For the present-day student of the phenomenon 'life,' the fact that zoe is experienced without limitations is only one of its aspects, not the whole. [...] Zoe is the minimum of life with which biology first begins" (Kerényi 1976a: xxxiv). In Kerényi's view, the modern interpretation of zoe could be connected mostly to molecular biology's minimum-definition of life. This interpretation of life is based on the phenomena of assimilation and inheritance and their consequences: growth, reproduction, evolution (Kerényi 1976a: xxvii). By this explanation, Kerényi implicitly opposes the basis of the Heideggerian ontology which, on the one hand, promotes a return to the Greek notions of Nature as physis ( $\varphi v \sigma_{\sigma l \varsigma}$ ) and the recovery of the classical concepts of Being, but, on the other hand, separates itself from the biological attributes of life (cf. "zoe [...] lends itself juxtaposition with physis" [Kerényi 1976a: 6]). In this, it almost entirely overshadows the ancient Cretan notion of zoe by highlighting the Aristotelian notion of physis in an imbalanced manner. The idea of the indestructibility of life, as an archetype, appears not only in Greek culture, but, in certain variations, can also be found again and again in the most remarkable manifestations, works, and cultural products of several religious systems. The indestructibility of life, according to Kerényi, is then not only the core experience of existence in ancient Greek society, but, as an archetype, it is one of the basic cultural images that are the central notions of human existence itself (Kerényi 1976a: xxvii).

According to Kerényi, it was Dionysos who became the most powerful mediator of the experience of zoe and its transformations (Kerényi 1976a: xxxvi-xxxvii). Through the figure of Dionysos, and within the framework of cultic activities, celebrations, and feasts connected to him, the experience of indestructible life could penetrate into the polis $(\pi \dot{\lambda} \lambda l \varsigma$ ), which was the domain of bios and subject to public 
law (vó $\mu$ ). From the strong visual representations of the Dionysos cult, it can be concluded that the cult's practice, serving as the direct sensual transfer of the rich experiences of zoe, followed extremely affective patterns which exploited the perceptual and in some cases the full bodily abilities of the cult members. As the artworks and different visual representations of the Dionysos cult show, the ancient religion of Crete contained several elements that were radically foreign to the culture of the Greeks of later times, as well as to Christian culture (Kerényi 1935a: 39). While classical Greek culture and Christian belief is partly directed at anthropomorphic but still spiritual gods in their essence, the gods of the ancient religion of Crete are rather seen to be rooted in the Cretan flora and fauna; moreover, the Cretan people considered the real creatures of their surroundings as the parousias of their gods.

If the plants and animals themselves gained such high respect in the ancient Cretan religion, the explanation to the following question helps us to understand the cult: what were their views of the human? Kerényi's point of departure regarding the human aspect of the Cretan Dionysos cult is H.A. Groenewegen-Frankfort's Arrest and Movement: An Essay on Space and Time in the Representational Art of the Ancient Near East (cf. Kerényi 1976a: 10-11). In this work, Groenewegen-Frankfort further developed the methodology of German structural archaeology and, following Otto's method in examining the proximity between cult members and the godhead, drew attention to the lack of distance in several cases between the human and the transcendent level in Cretan art, which is regularly reflected in easily identifiable symbols in the cultic representations. In many examples of Cretan art, the gods are not represented as historical personalities or heroes, but as plants, insects, birds, and sea animals, or they are simply manifested in some unusually expressive gestures as seen in representations of humans. The expressive gestures in those depictions refer to all 'things' that are beyond the physical body and belong to the transcendent sphere. In order to illustrate this, Kerényi uses representations of bullfighting, especially the famous bull-leaping scenes, which are among the most enigmatic, one might say, visionary pieces of Minoan art. In connection to the strange visionary character of the cultic art of the Cretans, Kerényi determines the epistemological relationship between vision, myth, and mythology in a remarkable way:

In accounts of ancient religions, too little attention has been paid to the visionary faculty. [...] The myth of the gods is divine epiphany in the medium of language. It is not localized in the same way as visions. It can be related wherever its language is spoken. A vision always has as its setting a definite place, the place where it occurred. [...] This localization is a heritage of vision in myth and in all the tales that embody it, that is, in mythology. [...] Vision and myth, epiphany and mythology, influenced and engendered one another and gave rise to cult images. But in man's relation to the gods, epiphany has a priority grounded in the immediacy of every true vision. Visions and language are equally fundamental, and both are presuppositions of the mythological tale. In Crete visions are especially important. Cretan mythology has not come down to us in its own language. [...] The Minoan gesture presupposes the possibility of epiphanies produced and made credible by a visionary capacity. The gesture brings transcendence into nature. 
[...] The visionary capacity was also stimulated and satisfied by Minoan art, which provoked a preliminary state, followed by another in which transcendence was induced by more violent means. [...] A true gesture is always an excerpt; its representation is an instant view of a movement. Minoan art succeeded in combining hints of transcendence with the utmost naturalness in representing scenes whose character is unmistakable. [...] Cretan mythology has preserved the gestures. To us it is a mythology of images that speak for themselves. (Kerényi 1976a: 14-22.)

Groenewegen-Frankfort called attention to the exceptionally dynamic character of Cretan visual art objects because they multiply the experience of organicity (Groenewegen-Frankfort 1951: xxiii). She found important - and Kerényi also shared this view - that, while in many other cases of cultic arts, "[b]easts and plants had served as accessories of man's pursuits, 'scenery' as a setting for his actions. But [in Cretan art,] nature was self-sufficient as pictorial content" (GroenewegenFrankfort 1951: 196). Groenewegen-Frankfort also quotes Ludwig Curtius' Die Antike Kunst, which characterizes the natural scenes of Cretan art as 'überhaupt Leben', life absolute (Groenewegen-Frankfort 1951: 197). But the most important element of Groenewegen-Frankfort's research for Kerényi was perhaps the following:

Cretan art ignored the terrifying distance between the human and the transcendent which may tempt man to seek a refuge in abstraction and to create a form for the significant remote from space and time; it equally ignored the glory and futility of single human acts, time-bound, space-bound. In Crete artists did not give substance to the world of the dead through an abstract of the world of the living, nor did they immortalize proud deeds or state a humble divine attention in the temples of the gods. Here and here alone the human bid for timelessness was disregarded in the most complete acceptance of the grace of life the world has ever known. For life means movement and the beauty of movement was woven in the intricate web of living forms which we call 'scenes of nature'; was revealed in human bodies acting their serious games, inspired by a transcendent presence, acting in freedom and restraint, unpurposeful as cyclic time itself. (Groenewegen-Frankfort 1951: 216)

Contrary to other interpretations, which emphasize the ecstatic, intoxicating character of Dionysos over its vegetative and natural aspect, Kerényi interpreted opium, an important means of intoxication and experiencing visionary images in the Dionysos cult, also from the aspect of the cult's radical orientation towards nature. Referring to De Quincey, Baudelaire, and Cocteau, Kerényi discusses opium not only as a drug that brings on delirium, but also as a nostrum that expands the boundaries of perception and stimulates and exaggerates the impressions that come from the natural environment (Kerényi 1976a: 26).

Since all of the elements of the Dionysos cult had a pervasive and radiant character, the cult's practice did not only happen within the framework of its celebrations, but many of its elements penetrated into other festivals and occasions of the year (Kerényi 1976a: 52). Kerényi's observations give proof that through this penetrating character of the Dionysian imagination, Dionysian representations of 
nature practically suffuse Cretan culture. As a result of the constant presence of zoe and the permanent experience of "living the idea of zoe", the cult members did not need to conceptualize the idea of zoe. Instead of a philosophic elaboration of the basic idea of the cult, zoe was rather expressed through, e.g., the use of masks, which mostly expressed animal characteristics within the framework of the rites (Kerényi 1976a, 80). By mixing animal and human characteristics during cultic activity, the spiritual transcendence of nature also became possible for the cult members. The cultic actions allowed abyssal psychosomatic energies to rise, thus - following a special dialectic pattern - the practice of the Dionysian cult of indestructible life could also include the cultic homicide of an individual (Kerényi 1976a: 218-219), as a way of "giving back" its bios to the constant flow of zoe. As a result, not only could the gestures of the enthusiastic celebrants of Dionysos affect the key activities of the cult, so could their resistance to Dionysos.

Kerényi presents a lively picture of female Dionysian initiatory celebrations as well as the stunned atmosphere at the tragedy contests witnessed by men. Drinking wine had a defining role during the whole period of the Great Dionysia, and serving wine during the tragedy contests was also continuous. The male audience of the tragedies wore ivy wreaths and, as depicted with great sensitivity by Kerényi, the viewers observed even the most delicate movement of the chorus with great enthusiasm and felt unified with the stage events. Kerényi considered these tragedy performances to be an example of the deepest religious devotions in the history of European religion. The audience's profound experience of the stage actions and identification with the chorus was also typical of comedy performances, too. The Old Comedies often impersonated the choir as different cultic species. In several plays, the choir of frogs, fish, ants, griffins, wasps, flies, bees, nightingales, storks and other birds, goats, or at many times only a "choir of animals", ruled the stage (Kerényi 1976a: 342). The viewers' experience of union with zoe happened during comedy performances as well, and with such intensity that the male spectators donned wreaths, masks, and acted as spirits (Kerényi 1976a: 317-318), bringing them rather close to the world of the animals. However, despite this ecstatic vehicle, these Dionysian animal choirs did not encourage bestiality; rather, they animated a peaceful mythical world based upon utopian desire. As Kerényi himself puts it, these acts "led to a fairy-tale world, the better world of wishes" (Kerényi 1976a: 342).

According to Kerényi's examples, comic unrestraint (or mockery and ridicule) is not part of New but Old Comedy. In New Comedy, what is universal is "philanthropeia, human sympathy," which would lead a community to mutual acceptance of one another's foibles. In particular, the atmosphere of Menander's comedy was explicitly philanthropic; in it, the humanistic aspect of the Dionysos-cult manifested itself, which in turn presaged, in Kerényi's words, the possibility of a "true humanism" in European culture (Kerényi 1976a: 348). The universalization of the Dionysian religion happened in the same course: the Dionysos cult became a cosmic and cosmopolitan religion in late antiquity (Kerényi 1976a: 387-388).

One of the key notions of Kerényi's Dionysos, indestructible life, was also of central importance to Nietzsche (cf. KSA '1.56', KSA '1.109'), who recognized a 
variety of expressions in the different mythologems connected to Dionysos. Simply put, as a polytheistic religion, it welcomes a multiplicity of types versus the single type prescribed by monotheism, which, as Nietzsche observes, translates the morality of custom "definitively into flesh and blood. In polytheism, the free-spiritedness and many-spiritedness of humanity received preliminary form - the power to create for ourselves our own new eyes and ever again new eyes that are ever more our own so that for humans along among animals there are no eternal horizons and perspectives" (GS §143; KSA 3:490). Relatedly, the cult of Dionysos recognizes the biological and philosophical interdependence of human existence and the natural world, locates this in the non-dividable double bind of the Dionysian animal and vegetative character, an aspect of zoe and physis. According to Kerényi (1976a: 348), it seems that the most important elements of the Dionysos cult can be found in his concept of "true humanism" to such an extent that it approaches the post-humanistic Nietzschean standpoint and leaves Kantian anthropology behind.

\section{BIOPOLITICAL PERSPECTIVES}

\subsection{AGAMBEN'S “BARE LIFE” AND KERÉNYI'S ZOE}

With Homo Sacer, Agamben made a significant impact on notions of biopolitics by calling attention to the biopolitical potential concealed in the distinction between zoe and bios (Agamben 1998: 1-12). Agamben describes zoe and bios mainly through Aristotelian and Platonic frameworks, but in his basic elucidation of these concepts, he identifies a much narrower and much less differentiated field of meanings and connotations than does Kerényi. First, Agamben doesn't seem to be cognizant of the reconstruction of the basic concepts' ancient registers, or their complex associative layers. Second, their introduction into contemporary notions of biopolitics does not take place in a satisfactory form; instead, Agamben presents a rather simplified definition of both concepts: "zoe [...] expressed the simple fact of living common to all living beings (animals, men, or gods), and bios [...] indicated the form or way of living proper to an individual or a group" (Agamben 1998: 1). The too brief and vague introduction of the concepts is followed by their more or less arbitrary use; Agamben's ideas therefore lack precision and clarity and make comprehending them problematic.

When outlining his notion of biopolitics, Agamben adopts Aristotle's view of zoe's exclusion from the polis (Agamben 1998: 2). Then, he introduces the biopolitical turning point of modernity as the politicization and re-entering of zoe as 'bare life' (la vida nuda) into the sphere of the "polis", which led to the politicalphilosophical transformation of the classical concept. This means that bare life itself became the main stake and operational ground of modern global politics:

Placing biological life at the center of its calculations, the modern State therefore does nothing other than bring to light the secret tie uniting power and bare life, thereby reaffirming the bond (derived from a tenacious correspondence between the modern and 
the archaic which one encounters in the most diverse spheres) between modern power and the most immemorial of the arcana imperii. (Agamben 1998: 6)

According to Agamben, Foucault's focus on political techniques and technologies of the self needed to be corrected or, at least, completed. What characterizes modern politics is the decisive fact that, together with the process by which the exception everywhere becomes the rule, the realm of bare life-which is originally situated at the margins of the political order-gradually begins to merge with the political realm and become indistinguishable from it (Agamben 1998: 2). One extreme version of this biopolitical process was when the Nazis and fascists transformed the concept of bare life into a supreme political principle (Agamben 1998: 10). To dispense with such tendencies in Western biopolitics, Agamben suggests reconsidering the Aristotelian definition of the polis as the opposition between life and good life, because he holds the opposition to be an implication of bare life in politically qualified life. From this configuration the question follows: "In what way does bare life dwell in the polis?" (Agamben 1998: 7) Agamben gives a rather Rousseauian answer to this question: "The fundamental categorial pair of Western politics is not that of friend/enemy but that of bare life/political existence, zoe/bios, exclusion/inclusion. There is politics because man is the living being who, in language, separates and opposes himself to his own bare life and, at the same time, maintains himself in relation to that bare life in an inclusive exclusion" (Agamben 1998: 8). But this problem cannot be solved through invoking the ancient Roman juridical concept of homo sacer, which is connected to Agamben's notion of bare life: "The protagonist of this book is bare life, that is, the life of homo sacer (sacred man), who may be killed and yet not sacrificed, and whose essential function in modern politics we intend to assert" (Ibid.). The difficulty stems from Agamben's arbitrary way of using concepts when he speaks of the "liberation of zoe" as searching for the "bios of zoe". However, what he sees as the invention of a new politics, constructing a link between zoe and bios (Agamben 1998: 11.), is actually an idea that can be actualized in a contemporary context, and which exist as potentials in Kerényi's interpretation of zoe and bios.

But the relative coherence of Agamben's theory is repeatedly undermined during the broader explanation of his ideas by his unclear and simplified definitions of zoe and bios. Additionally, Agamben does not define the punctual relationship between his own "bare life" concept and the ancient Greek notion of zoe carefully enough. Similarly, his repeated identification of zoe with bare life is reductive, limiting the protean sense and discursivity of the ancient Greek concept, as do modern western languages through naming the ancient Greek concepts of life with one single expression. Ultimately, this conceals, or certainly occludes, the distinction sustained in the ancient Greek concepts of zoe and bios. Let us state here that biopolitics have both positive and negative senses; as Esposito argues, "a politics in the name of life," and that of a "life subjected to the command of politics" (Esposito 2008: 15, emphasis added). One can even bifurcate the affirmative aspect and differentiate between say, to give two prime examples, an American conception of biopolitics, which is rooted 
in naturalistic, evolutionary justifications, and a Nietzschean biopolitics, which is anti-naturalist and contra-evolutionary. To think biopolitics is then to think a variegated range of political values, not any single one, and in this we see that Kerényi's interpretation of $z o \bar{e}$ as "indestructible life," insofar as it holds any "biopolitical potential," is far more affirmative or positive (even utopian) than Agamben's. To clarify why, we will illustrate why Agamben's conflation of zoe and bare life is problematic.

Agamben's definition of the relationship between zoe and bare life has a number of consequences. First, the concepts seem to be synonymous: "The fundamental categorical pair of Western politics is not that of friend/enemy but that of bare life/political existence, zoe/bios, exclusion/inclusion" (Agamben 1998: 8). Further: "zoe - the bare, anonymous life that is as such" (Agamben 1998: 124). If Agamben would not make zoe and bare life synonymous, consequently, he would have to use the term "bare life" and not zoe. Moreover, his use of the word zoe in certain contexts is distorted; for example, when he interprets the body of the Fuhrer: "The Fuhrer has, so to speak, a whole body that is neither private nor public and whose life is in itself supremely political. The Fuhrer of the Third Reich's body is, in other words, situated at the point of coincidence between zoe and bios, biological body and political body. In his person, zoe and bios incessantly pass over into each other" (Agamben 1998: 184-185). Similarly here: "What is the life of the Muselmann? Can one say that it is pure zoe?" (Agamben 1998: 185) And when Agamben describes the case of the overcomatosed person, Karen Quinlan, he use the expression "bare life" (Agamben 1998: 164) while in another case, he uses the word for describing the same phenomenon "pure zoe" (Agamben 1998: 186). If Agamben's notion of "bare life" is not a translation or lexical explanation of $z o \bar{e}$, but rather an interpretation, or conceptual elaboration of the term, it certainly does not have the same status as Kerenyi's notion of "indestructible life." To conflate these concepts and see no distinction between the body of the Fuhrer, the Muselmann of the concentration camp, and a comatose person is to offer a definition with no particularity whatsoever.

These discrepancies and essentializations are also not resolved by The Agamben Dictionary. Under the entry "Bare Life", Arne De Boever writes that bare life is neither identifiable with bios, nor zoe, but "rather, it is life that is produced whenever $z o e ́$ is separated from bios, and bios (ethical and political life) calls zoé (biological life) into question" (The Agamben Dictionary 2011: 30-31). The discrepancies shown by the examples of Agamben's description of the case of the Fuhrer, the Muselmann, and Karen Quinlan are not in any way resolved but only placed under the concept of bare life in The Agamben Dictionary: "At the end of Homo Sacer, Agamben offers what, as he himself acknowledges, may seem like an "extreme, if not arbitrary" (Agamben 1998: 186) list of other figures of bare life: "the Flamen Diale, one of the greatest priests of classical Rome"; "the bandit"; "the Führer in the Third Reich"; "Wilson, the biochemist who decided to make his own body and life into a research and experimentation laboratory"; and the over-comatosed person, Karen Quinlan" (Agamben 1998: 182-6). (The Agamben Dictionary: Ibid.). We can see that not only is the selection of these figures "extreme, if not arbitrary", but so is the terminology 
that Agamben uses to describe them. From this, it is already obvious that it is not purely accidental that, for Agamben's interpreters, defining the relationship between the concept of bare life, zoe, and bios, is problematic, for Agamben is also inconsistent in his use of these terms. Moreover, he uses a fourth expression as well, "sacred life" (Agamben 1998: 90, 131), which, according to The Agamben Dictionary (2011: 172), we would have to understand as a synonym of bare life.

One of the most incisive critiques of Agamben's theory was made by Jacques Derrida, who in his final seminar, The Beast and the Sovereign (2009), criticized Agamben for his tendency to speak of the origin of ideas and concepts (cf. Swiffen 2012). Derrida questions the soundness of Agamben's notions of zoe and bios, as well as his method of formulating this question. For example, Derrida considers Agamben's "translation" of zoe as bare life audacious (2009: 326); further, he finds Agamben's references to bare life's politicization a decisive event of modernity not satisfying enough:

I don't believe, for example, that the distinction between bios and zoe is a reliable and effective instrument, sufficiently sharp and, to use Agamben's language, which is not mine here, sufficiently deep to get to the depth of this '[so-called] founding event.' Nor that the category of forgetting is sufficiently pertinent here for a more or less competent philologist, capable of seeing the difference between bios and zoe, to reawaken politics to itself today and make it come out of its oblivion or its sleep. The more so in that said philologist must repeatedly recognize that not only did Aristotle, many centuries ago, talk of zoon politikon (and that the "plus": zoon + politikon is, as we shall see in a moment, a very fragile threshold), but that sometimes, and I recalled earlier an example to do with God, zoe designates a life that is qualified, and not 'bare.' (Derrida 2009: 326-327)

Derrida makes another convincing observation when he states that "bio-power" itself is not a new phenomenon (Derrida 2009: 330), and further: "in Aristotle there's a thinking of what is today called 'zoopolitics' or 'biopolitics.' Which doesn't mean [...], of course, that Aristotle had already foreseen, thought understood, analyzed all the figures of today's zoopolitics or biopolitics: it would be absurd to think so. But as for the biopolitical or zoopolitical structure, it's put forward by Aristotle, it's already there, and the debate opens there" (Derrida 2009: 349).

In addressing various conceptions of biopolitics and the use of the terms bios, polis, vita, and zoe, Laurent Dubreuil remarks that both Agamben and Esposito "dress their works in a philology that cuts through history" (Dubreuil 2006: 83). Dubreuil points out the anomalies stemming from Agamben's philological imprecision and details the problems with his references to Hannah Arendt as well, who, also refers to the concepts of zoe and bios in The Human Condition (Dubreuil 2006: 85). Yet, Agamben's critics, including Derrida, do not refer to classical-philological explanations, such as Kerényi's (1963b). If so, they may have seen that Kerényi's analysis is in line with Arendt's understanding of bios and zoe and, as Stephan Grätzel also points out, Kerényi's classical-philological interpretation stands firmly against Agamben's use of the concepts of zoe and bare life (Grätzel 2004: 28-30). 


\subsection{DIONYSIAN BIOPOLITICS AND KERÉNYI'S EXPERIENTIAL HUMANISM}

Instead of the image of an idealized and, one might say, Christianized antiquity, which was based on classical ideology (Emden 2004), taste, and morality, and which served as a model for modern European mainstream culture until the twentieth

century, Kerényi succeeded in introducing a social idea that is deeply rooted within the order of an antique society through a whole system of community practices, but which is almost in every aspect different from the cultural notions and social practices that are indigenous to the Western Judeo-Christian tradition. By stressing the difference between bios and zoe, and by the deep analysis of zoe's multi-layered cultic and mythological representations, Kerényi's results can open new research perspectives and enable a further examination of the deep structures of contemporary biopolitical, bioethical, and biocritical concepts as well as their relationship to the philosophy of antiquity. It is remarkable that in the medico-ethical praxis of today, e.g., modern scientific views on the start of individual human life correspond to Kanamori's analogy of the antique concept of the limited period of bios emerging from the infinite and constant flow of zoe (cf. Kanamori 2007). But, when does human biological life begin? Does human life start with the emergence of the embryo, or earlier? And when do obligations to protect human life begin? (cf. Kurjak et al. 2009) The answers to these questions are never definite. The interpretation of the minimum definition of life in a biological sense, and the scientific theories and legal practices resulting from these theories in regard to determining the beginning of the individual human life (cf. Mills 2011), are issues that constantly form a social and political debate. They cannot be made, in all respect, consistent with religious doctrines or different ideologies based on moral considerations, political standpoints, and philosophical systems.

By establishing a model that puts the zoe-bios difference into the concept of life, and showing this idea to be a basic model of ancient Greek ontology, Kerényi took a critical viewpoint opposing Heidegger, who emphasized the absolute priority of the Greek notion of physis in his theory of Being. As explained by Kerényi, the concept of zoe can illustrate the dangerous restrictions of Heideggerian philosophy since it displaces notions of bios and disregards the complex existential bio-philosophical problems of the body, and ignores questions of animality (cf. Acampora 2006; Aho 2009). Kerényi's zoe concept radically claims the continuity of human and animal existence whereas in Heidegger's interpretation, although the animal lives in the environment of the human, it does not share the same Being, nor the same World (Heidegger 1992: 308). The elaborate answers for questions concerning animality and related issues also often result in direct political stands that, obviously, are contentious if rooted in Heideggerian philosophy. Still, any philosophy of Being needs to be able to provide a proper philosophical framework and discourse to deal with such timely questions of our political and ethical communities, like, e.g., the problem of biological experiments, genetic modification, the minimum definition of life, the treatment of living material, regulations concerning the protection of human 
life, animal rights or, recently, even plant rights. But, partly due to the totalizing introduction and interpretation of a certain notion of physis, Heideggerian philosophy provides a rather narrow scope of philosophical experience and actions for examining such basic issues of contemporary bioethical and biopolitical discourses. Susanna Lindberg details in her article "Heidegger's Animal" how the bodily, "flesh and blood" aspects of existence and sensuality are forced into the margins of Heidegger's thought (Lindberg 2004). According to Lindberg, Heidegger creates a notion of Dasein that, unlike the traditional Aristotelian definition of the human being as a clever animal, holds the notion of human animality at a distance. Heidegger, as a philosopher of the human world and existence, pays rather little attention to the study of non-human forms of life. The notion of physis, which is the central thought of Heidegger's philosophy from around 1935, could create the possibility for elaborating a differentiated notion of nature in accordance with his original intentions. However, physis was introduced in Heideggerian philosophy as a basic notion in a totalizing way wherein the human quality of being left very limited space for the introduction of the notion of zoe and its far-reaching philosophical context.

Aristotle made a distinction between the soul of plants, animals, and humans. Despite the fact that Heidegger based the most important points of his ontological philosophy on Aristotle's philosophical concepts, although Aristotle associated the soul of animals with the ability of perception above all, for Heidegger, the bodily relation of animals to humans is unimaginable. Nevertheless, this does not mean that this experience is nonexistent or unknowable; rather, it means that the world of antiquity contained several cultural phenomena that are qualified as "unclean" from the viewpoint of the Judeo-Christian tradition, and these are under restriction even in Heideggerian philosophy. On the other hand, Kerényi's Dionysos interpretation developed systematic hermeneutical and epistemological strategies in order to bridge the cultural, moral, and aesthetic division between antiquity and the $20^{\text {th }}$ century while pointing forward to our own century.

In opposition to several predecessors and contemporaries in the study of religion, Kerényi introduced Dionysos' cultural role in Greek culture. Through that, he also introduced models of human and natural coexistence of collective identification with the experience of zoe as a central part of a complex semiotic system. The Dionysoscult in Kerényi's interpretation is a basic and meaningful component of the culture of the polis and not a peripheral religious historical formulation. By taking up Foucault's term, we might say that the Dionysos cult performed a heterotopic function in the polis. Through the system of exclusions and inversions, it had a balancing and dynamizing role that was related to the inner structure of the polis. Dionysos appeared as a kind of life guide for the men and women of the polis; he accompanied them in their individual and biological transformations; he was present at every turning point of their biographic course of life (Isler-Kerényi 2007: 104-105). and at every important moment of the changing of their social status. This can be supported by the fact that, in spite of the romantic generalizations of Dionysos as the god of insane joy, in certain portrayals he is depicted in a kind of stabilizing and civilizing role. However, this role is not limited to the territory of civilization but, in a connective 
way, it is expanded to wild nature and to such transitional territories as groves, meadows, and agricultural fields. But in each case, it is closely connected to the polis (Isler-Kerényi 2007: 135).

In Kerényi's analysis, it is also remarkable that, in his interpretations of zoe, and also in the selected mythical examples with which he demonstrated the incorporation of the Dionysos cult into Greek culture, those myth variants are almost consistently prioritized, as they were when Kerényi created his Dionysian philosophy (pace Nietzsche). The position regarding nature in Nietzsche's philosophy, the Nietzschean "eco-philosophy" (cf. Parkes 1998) and its animalist tendencies, have been analyzed by many commentators. In Nietzsche's Animal Philosophy, Vanessa Lemm observes that, through the Nietzschean affirmation of animality, a way is outlined for going beyond the limits of Kantian anthropology, and a new kind of humanism can be established based on the acceptance of the variety and individuality of different lifeforms (Lemm 2009).

Although Lemm does not refer to Kerényi, her considerations are in line with Kerényi's discussions of zoe and their philosophical implications. Kerényi's own position is "that of a historian, and at the same time that of a rigorous thinker" (1976a: XXXVII), and he describes his approach as a "differentiated thinking about the concrete realities of human life" (ibid). He opposed this differentiated thinking to the mainstream classical studies of his age, which offered much more limited access to those "realities of human life", which needed to be examined from biopolitical perspectives as well. Kerényi's approach is totally different from the other specialists of classical studies of his age:

The summary thinking that has become dominant (under the influence of Sir James Frazer) in the study of the peoples of antiquity and in the study of Greek religion (especially under the influence of Martin P. Nilsson and Ludwig Deubner) cannot take these realities into account. True, when we consider them in all their concreteness, we are forced to admit that today the destruction of all life has become conceivable. Yes, conceivable, but not from the standpoint of life, only from that of history which, as we now know on the strength of our own historical experience, may lead to universal destruction. According to the minimal definition of life current today, 'assimilation and heredity (and their consequences: growth, reproduction, and evolution) ... distinguish living from dead matter.' Because life includes heredity-otherwise it would not be life - it transcends the limits of the individual, mortal, living creature and proves in every individual case, regardless of whether or not the heredity is actually realized, indestructible. Life presupposes heredity and so possesses the seed of temporal infinity. The seed is present even if nothing springs from it. Thus, we are justified in speaking of 'indestructible life,' in finding its archetypal image in the monuments of religion, and in pointing to its value for religious man as a historical experience. (Kerényi 1976a: XXVII-XXVIII).

From a biopolitical perspective, we find that, similarly to Agamben, Kerényi's Dionysos also deals with the turning points of human history when zoe entered the world of politics, i.e., the polis. But Kerényi's particular example, the case of the 
Dionysian cult, is entirely different from those examples that Agamben described in Homo Sacer. Agamben's examples describe the Greek idea of zoe's complete alienation from modern western culture, based on the process of zoe's transformation into bare life through the idea's politicization. While in Dionysianism, as it is described by Kerényi, the contrary is happening. The idea of zoe does not have to be politicized or philosophically formulated to enter into the world of the polis because in being concealed in the language and expressed in Dionysianism, it is already present. On the level of language, and as expressed through the acts of the Dionysian cult, the zoe-centered Dionysian worldview is at once directly incorporated into the world of the polis:

The distinction between infinite life and limited life is made in the Greek language by the two different words zoe and bios. Such a distinction was possible in Greece without the intervention of philosophy or even of reflection because language is the direct expression of experience... (Kerényi 1976a: XXVIII.)

A brief investigation of the meaning of the two Greek words for "life" may help to introduce the reader - whether or not he knows Greek — to this experience. [...] 'Did the Greeks ever have such ideas about Dionysos as Otto's or these? They had it easier. For in myth and image, in visionary experience and ritual representation they possessed a complete expression of the essence of Dionysos. They had no need, as we do, to look for an intellectual formulation, which must always remain incomplete. (Kerényi 1976a: XXVIII-XXIX.)

The experience of life without characterization —of precisely that life which "resounded" for the Greeks in the word zoe on the other hand, indescribable. It is not a product of abstractions at which we might arrive only by a logical exercise of thinking away all possible characterizations. (Kerényi 1976a: XXXV.)

While Kerényi examines some aspects of the contemporary biological context of the Greek idea by referring to modern biology, he also introduces Dionysianism as a predecessor in many ways to later notions of cosmopolitanism and humanism. It is not possible to discuss the details of Kerényi's specific humanism in this article, but it should suffice to note that Kerényi took biopolitical perspectives as well in the development of his own unique standpoint into account. ${ }^{6}$ For example, Kerényi's Enkomion auf Willibald Pirckheimer (1988), reveals that he actively followed the work of scholars such as Julian Huxley, who coined the term transhumanism, and whose theories made a great impact on contemporary biopolitical discourse. Kerényi refers to Huxley's Evolutionary Humanism and criticizes it because of its abstractness: according to Kerényi, humanism has to concentrate on concrete experiences. This means that there can be a new alternative for biopolitics as well, if contemporary culture and science could support the direct and concrete experience of zoe as it once already existed in the course of history in the form of Cretan Dionysianism.

\footnotetext{
${ }^{6}$ These can also be examined in connection with the biopolitical considerations of his Dionysos.
} 


\section{CONCLUSION}

If there was no concrete conception of the self in ancient Greece, and presumably in Crete, then, what this essentially illustrates is a more porous and contiguous relationship between man and nature. Morris Berman seems to confirm this view with his observation that, since the ancient Greeks "made virtually no distinction between subjective thought processes and what we call external phenomena [..., the individual is immersed in a sea of contradictory experiences and learns about the world through emotional identification with it (original participation) ..." (Berman 1981: 71) The barrier then, at least in part, is the modern conception of subjectivity, which is - according to Nietzsche - essentially based on the Christianized Platonic tradition of interpreting nature. As opposed to the contestatory relationship between man and nature established by the onto-theological tradition, through Dionysos, a more holistic one can exist. In The Veil of Isis, Pierre Hadot outlined two paradigmatic attitudes toward nature, which he characterizes mythically, as Promethean and Orphic. The first represents a dominating, instrumental disposition, the second, its opposite. Through the Dionysian ethos, it is clearly possible to reanimate the harmonious Orphic versus the disharmonious Promethean relation to nature and the world. According to Kerényi, this is within our reach.

\section{ACKNOWLEDGMENTS}

I would like to thank the anonymous reviewers for their valuable comments and suggestions to improve the quality of the article. I am also grateful to Abe Hiroshi (Kyoto University), Mario Wenning (University of Macau), Rainer J. Hanshe (Contra Mundum Press / Hyperion Art Journal), Prof. Tuomo Lahdelma (University of Jyväskylä), Prof. György Tverdota (Eötvös University), Prof. Beáta Thomka and Dr. Jolán Orbán (University of Pécs) who supported my work and to Rien Bongers for the photograph of the Cumae amphiteater.

\section{REFERENCES}

Note for abbreviations in the text:

GS: Friedrich Nietzsche: The Gay Science

KSA: Friedrich Nietzsche: Sämtliche Werke. Kritische Studienausgabe

Acampora, Ralph R. (2006), Corporal Compassion: Animal Ethics And Philosophy Of Body (Pittsburg: University of Pittsburg Press).

Agamben, Giorgio (1998), Homo Sacer. Sovereign Power and Bare Life. Trans. by Daniel Heller-Roazen (Stanford: Stanford University Press).

Agamben, Giorgio (1995), Homo Sacer: Il Potere Sovrano e la Nuda Vita (Torino: Einaudi). 
Murray, Alex and Jessica Whyte (eds.) (2011), The Agamben Dictionary (Edinburgh: Edinburgh University Press)

Aho, Kevin A. (2009), Heidegger's Neglect Of The Body (New York: SUNY Press).

Berman, Morris (1981), The Reenchantment of the World (New York: Cornell University Press)

Derrida, Jacques (2009), The Beast and the Sovereign: trans. Geoffrey Bennington Vol. I (Chicago: Chicago University Press).

Dubreuil, Laurent (2006), "Leaving Politics: Bios, Zoé, Life," Diacritics 36 (2): 8398.

Emden, Christian (2004), "The Invention of Antiquity: Nietzsche on Classicism, Classicality, and the Classical Tradition", In Paul Bishop (ed.), Nietzsche and Antiquity. His Reaction and Response to the Classical Tradition, (Rochester, NY: Camden House), 372-90.

Esposito, Roberto (2008), BIOS: Biopolitics and Philosophy (Minnesota; London: University of Minnesota Press).

Grätzel, Stephan (2004), Dasein ohne Schuld. Dimensionen menschlicher Schuld aus philosophischer Perspektive (Göttingen: Vandenhoeck \& Ruprecht).

Groenewegen-Frankfort, H. A. (1951), Arrest and Movement:An essay on space and time in the representational art of the ancient Near East (London: Faber and Faber).

Hadot, Pierre (2008), The Veil of Isis: An Essay on the History of the Idea of Nature (Belknap Press).

Heidegger, Martin (1992), Die Grundbegriffe der Metaphysik (Frankfurt am Main: Vittorio Klostermann).

Isler-Kerényi, Cornelia (2007), Dionysos in Archaic Greece:An Understanding through Images; trans. Wilfred G. E. Watson (Leiden - Boston: Brill).

Kanamori, Osamu (2005), Philosophy of Genetic Modification (Tokyo: Keiso Shobo).

--- (2007) ,"Bios and his Self-armor" , Journal of Philosophy and Ethics in Health Care and Medicine, 2007, July, 26-43.

---- (2008), "Autour de la question de Bios et de Zoe", (Lecture at Autour du corps humain: Bioéthique comparée France-Japon. 4-5 September 2008, Centre Georges Canguilhem, Paris: $<\quad$ http://centrecanguilhem.net/wpcontent/uploads/2009/03/autour-de-la-question-de-bios-et-de-zoe-parosamukanamori.pdf - retrieved on 28.2.2014.>

Kerényi, Karl (1934), “Ókortudomány”, (Ancient Studies) Válasz 1: 304-314.

---- (1935a), "Gedanken über Dionysos", Studi e Materiali di Storia delle Religioni, XI, 11-40.

----(1935b), Dionysos und das Tragische in der Antigone. Frankfurter Studien zur Religion und Kultur der Antike 13, Walter F. Otto(ed.) (Frankfurt a. n: Vittorio Klostermann.).

----(1937),“Über Krise und Möglichkeit der klassischen Altertumswissenschaft,” Europäische Revue XIII, 965-976.

---- (1940a), Die antike Religion. Eine Grundlegung (Amsterdam: Pantheon and Leipzig: Haag-Drugulin). 
---- (1940b), La religione antica nelle sue linee fondamentali;Trans. Delio Cantimori (Bologna: N. Zanichelli).

----(1956), Die Herkunft der Dionysosreligion nach dem heutigen Stand der Forschung. Arbeitsgemeinschaft für Forschung des Landes Nordrhein-Westfalen, 58. (Cologne and Opladen).

---- (1957), “Dionysos le Crétois,” Diogene, XX, 2-27.

---- (1959), Asklepios: Archetypal Image of the Physician's Existence. BS LXV. 3. trans. Ralph Manheim (Princeton: Princeton University Press).

---- (1961), Der frühe Dionysos (Oslo: Oslo University Press).

---- (1962a), Die Mysterien von Eleusis. (Zürich: Rhein Verlag).

----(1962b), Religion of the Greeks and Romans(London: Thames and Hudson). (A translation by Christopher Holme of Die Religion der Griechen und Römer, Munich, 1963. Both versions are based on Die antike Religion, originally published in 1940 [cf. Kerényi 1940a]).

---- (1963a), Prometheus: Archetypal Image of Human Existence;trans. Ralph Manheim BS LXV. 5 (Princeton: Princeton University Press).

----(1963b), "Schicksal, Leben und Tod nach griechischer Auffassung", Beiheft zur Schweizerischen Zeitschrift für Psychologie und ihre Anwendungen, Nr. 46 (Bern und Stuttgart: Hans Huber Verlag): 5-16.

---- (1967), Eleusis:Archetypal Image of Mother and Daughter;trans. Ralph Manheim BS LXV. 4. (Princeton: Princeton University Press).

---- Jung C. G. (1969), Essays on a Science of Mythology. The Myth of the Divine Child

and the Mysteries of Eleusis. Bollingen Series, 22 (Pantheon Books)

---- (1975), Zeus and Hera. Archetypal Image of Father, Husband, and Wife; trans. Ralph Manheim BS LXV. 5 (Princeton: Princeton University Press).

---- (1976a), Dionysos:Archetypal Image of Indestructible Life; trans. Ralph Manheim BS LXV. 2 (Princeton: Princeton University Press).

----(1976b), Dionysos. Urbild des unzerstörbaren Lebens (München and Wien: Langen Müller).

---- (1980), “Unsinnliche und sinnliche Tradition", in Apollon und Niobe (MünchenWien): 64-79.

----(1988), “Enkomion auf Willibald Pirckheimer", in Wege und Weggenossen Vol. 2. (München: Langen-Müller): 11-21.

Kurjak, Asim et. al. (2009), "The Ethical Concept of the Fetus as a Patient and the Beginning of Human Life", Periodicum Biologorum 111 (3): 341-348.

Lemm, Vanessa (2009), Nietzsche's Animal Philosophy: Culture, Politics, and the Animality of the Human Being (New York: Fordham University Press).

Lindberg, Susanna (2004), "Heidegger's animal”, Phänomenologische Forschungen NF 9, 57-81.

Mills, Catherine (2011), Futures of Reproduction: Bioethics and Biopolitics (Dordrecht, Heidelberg, London, New York: Springer). 
Nietzsche, Friedrich (1980), Sämtliche Werke. Kritische Studienausgabe. 15 vols. G. Colli and M. Montinari(ed.) (Berlin/New York: Walter de Gruyter, 1967-1977; Munich: Deutscher Taschenbuch Verlag) .

Otto, Walter F. (1965), Dionysus - Myth and Cult; trans. Robert B. Palmer (Bloomington / London: Indiana University Press).

Parkes, Graham (1998), "Staying Loyal to the Earth: Nietzsche as an Ecological Thinker", in John Lippitt (ed.), Nietzsche's Futures (Basingstoke: Macmillan).

Simon, László (2011), "Die sinnliche Tradition der Antike", in Pál Kelemen, Ernő Kulcsár Szabó and Ábel Tamás (eds.), Kulturtechnik Philologie: Zur Theorie des Umgangs mit Texten (Heidelberg: Winter), 105-124.

Swiffen, Amy (2012), "Derrida Contra Agamben: Sovereignty, Biopower, History", Societies 2: 345-356. 